\title{
弁膜症手術症例における口腔内病変の罹患率と対策
}

\author{
中 村 喜 次 ${ }^{1)}$ 田 鎖 治 ${ }^{1)}$ 斎 $\quad$ 藤 健 -2) 小山田 志 瑞 $^{1)}$ \\ 本田 賢太朗 ${ }^{1}$ 本 間 信 $2^{1)}$ 宮 本 亮 三 ${ }^{2)}$ 中 野清 治3)
}

\begin{abstract}
弁膜症患者の術前における口腔内病変の罹患率は不明である. 今回, 弁膜症手術患者の口腔内病変の罹患率 について調査，検討した．また菌血症をおこしうる病変があった場合，抜歯を術前に行った．抜歯が術後在 院日数に与える影響についても検討した。 2003 年 5 月から 2007 年 1 月までに施行した弁膜症手術患者 177 例中, 歯科受診した 137 例を対象とした。菌血症を呈する可能性のある化膿性歯周炎, 根尖性歯周炎を認め た場合，抜歯の適応とした。菌血症となりうるロ腔内病変を有し抜歯が必要であった患者は 82 例 (59.9\%) であった。 また軽度のう歯のため抜歯は必要なかったものの簡単な充﨏処置が必要であった症例 が 6 例 $(4.4 \%)$ であった。要抜歯患者の平均抜歯本数は 1.9 本（1１0 本）であった。抜歯による合併症

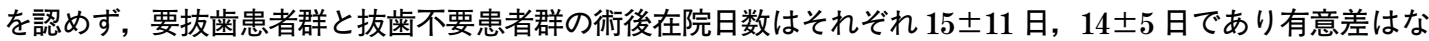
かった。平均観察期間 30 カ月中, 術後, 感染性心内膜炎を発症した症例はなかった。弁膜症手術症例の口 腔内病変罹患率は高く，㫕の多くは菌血症の原因となりうる病態であった。兰れら口腔内病変を有する患者 に対し弁膜症手術前に安全に抜歯が可能であり，術後経過を遷延させることはなく良好な結果を得た。日心 外会誌 37 巻 4 号 : 213-216 (2008)
\end{abstract}

Keywords：弁膜症，口腔内病変，罹患率，感染性心内膜炎，菌血症

\section{Prevalence of Dental Disease in Patients Undergoing Heart Valve Surgery}

Yoshitsugu Nakamura ${ }^{1)}$, Osamu Tagusari ${ }^{1}$, Kenichi Saito ${ }^{2)}$, Shizu Oyamada ${ }^{1)}$, Kentaro Honda ${ }^{1)}$, Nobuyuki Homma ${ }^{1}$, Ryozo Miyamoto and Kiyoharu Nakano ${ }^{3)}$ (Department of Cardiovascular Surgery $^{1)}$ and Department of Dentistry and Oral Surgery ${ }^{2)}$, Kanto Medical Center NTT EC, Tokyo, Japan and Department of Cardiovascular Surgery, Tokyo Women's Medical University Medical Center East ${ }^{3)}$, Tokyo, Japan)

Bacteremia from dental disease is the most important cause of infective endocarditis in patients with heart valve disease. However, the prevalence of dental disease in patients undergoing valve surgery has not been clarified. One hundred thirty-seven patients had a dental check-up before heart valve surgery, 82 patients $(59.9 \%)$ had significant dental disease which could have caused bacteremia. All patients with the dental disease underwent extraction preoperatively. There was neither complication in extraction nor any influence on heart valve surgery. Postoperative hospital stay was not prolonged due to the extraction. During the mean follow-up period of 30 months, no infective endocarditis was seen. The prevalence of dental disease was high in patients undergoing heart valve surgery. Preoperative treatment of dental disease did not have a negative impact on the postoperative course and hospital stay in heart valve surgery. Jpn. J. Cardiovasc. Surg. $37: 213-216$ (2008)

\section{背 景}

口腔内病変あるいは抜歯などの歯科治療は菌血症を引き 起こす可能性があり，感染性心内膜炎（IE）の最重要な リスクである ${ }^{1,2)}$. 特に弁膜症手術後患者は人工弁心内膜 炎を発症する危険が高く ${ }^{3)}$ ，その予後は不良である。しか しながら, 弁膜症を有する患者の口腔内病変はこれまで重 視されることもなく，罹患率すら不明である。

2008 年 1 月 7 日受付, 2008 年 4 月 10 日採用

1) NTT 東日本関東病院心臓血管外科

干 141-8625 東京都品川区東五反田 5-9-22

2) NTT 東日本関東病院歯科口腔外科

3) 東京女子医科大学東医療センター心臓血管外科
当科では 2003 年 5 月から，弁膜症手術を予定した患者 に対し術前に歯科口腔外科で口腔内病変をスクリーニング し，菌血症を引き起こしうる病変があれば抜歯を行ってか ら弁膜症手術を施行する方針としてきた。

本論文では手術予定の弁膜症を有する患者の口腔内病変 に関し検討した。

\section{対象と方法}

2003 年 5 月から 2007 年 1 月までに施行した弁膜症手術 患者 177 例中，歯科受診した 137 例を対象とした．近医で 歯科治療済み，あるいは治療中の患者，緊急症例で歯科受 診できなかった患者は除外した。

男性 84 例，女性 53 例，平均年齢 $65 \pm 10$ 歳，疾患の内 
訳は大動脈弁狭窄症 44 例, 大動脈弁閉鎖不全症 37 例, 僧 帽弁狭窄症 6 例，僧帽弁閉鎖不全症 39 例，連合弁膜症 10 例，三尖弁閉鎖不全 1 例であった。このうち IE は 13 例 であった（表 1).

以上の患者を対象に, 口腔内病変の罹患率をレトロスペ クティブに検討した．また口腔内病変を有する患者と有し ない患者群の術前状態を比較し, その疫学的特徴と術後在 位日数に与える抜歯の影響についても検討した。集計結果 は平均土標準偏差とパーセンテージで表記し, 両群間の比 較には $\chi^{2}$ 検定，Mann Whitney 検定を用いた。

抜歯の適応：全例，歯科口腔外科医師による診察と X 線所見を行い，それらをもとに口腔内病変の診断を行っ た。排膿所見や X 線写真上での骨吸収像があれば，顎骨 内に感染病巣, 化膿性病変を有する状態, 寸なわち菌血症 を呈する可能性のある化膿性歯周炎, 根尖性歯周炎（図 1）と診断し，抜歯の適応とした。

抜歯時の感染予防として感染症心内膜炎の予防と治療に 関するガイドラインに基づき，アモキシシリン $2 \mathrm{~g}$ を抜歯 の 1 時間前に全例内服するようにした . 抜歯のタイミン

表 1 患者背景

\begin{tabular}{lc}
\hline & 137 例 \\
\hline 男/女 & $84 / 53$ \\
年齢 (歳) & $65 \pm 10$ \\
大動脈弁狭窄 & 44 \\
大動脈弁閉鎖不全 & 37 \\
僧帽弁狭窄 & 6 \\
僧帽弁閉鎖不全 & 39 \\
連合弁膜症 & 10 \\
三尖弁閉鎖不全 & 1 \\
感染性心内膜炎 & 13 \\
\hline
\end{tabular}

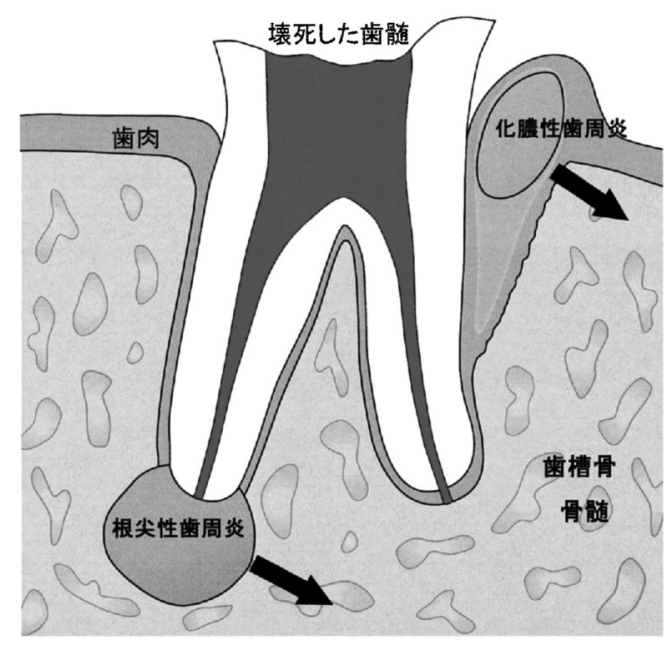

図 1 口腔内病変からの感染経路 口腔内病変から菌血症を起こす経路は化膿性歯周炎, 根尖性歯 周炎からの二つがある。矢印はその二つの経路を表す。
グは，原則的には手術の約 1 週間前から前日までの間に 行った。

\section{結果}

137 例の弁膜症手術対象患者のうち, 化膿性歯周炎, 根 尖性歯周炎を認め, 抜歯が必要であった患者は 82 例 (59.9\%) であった。また軽度のう歯のため抜歯は必要な かったものの簡単な充填処置が必要であった症例が 6 例 (4.4\%) であった（図 2). 手術は弁置換を 113 例, 弁形 成術を 24 例に施行した (表 2). 手術死亡, 入院死亡は無 かった。

菌血症となりうる口腔内病変を有する要抜歯群 (82 例) と抜歯不要患者群 (55 例) の術前状態の比較検討では年 齢, 疾患弁位, IE の有無, 心拍出量に有意差はなかった (表 3). 要抜歯患者群と抜歯不要患者群の術後在院日数は それぞれ $15 \pm 11$ 日，14 14 日であり有意差はなかった (表 2). 病変を有した群は全例, 抜歯を中心とした歯科治 療を行ったが，それに伴う合併症を認めなかった。また術 後抗凝固療法による抜歯部の出血も含め, 歯科治療が術後 経過を遷延させることはなかった。

平均抜歯本数は 1.9 本（1～10 本）であった（図 3$)$.た だし抜歯が多岐にわたるために 3 例では弁膜症術前に歯科 治療のための入院が必要であり弁膜症手術を延期した。ま たそのうち 1 例は上顎洞根本手術が必要であった。

平均観察期間 30 力月で両群ともに人工弁感染性心内膜 炎はなかった。

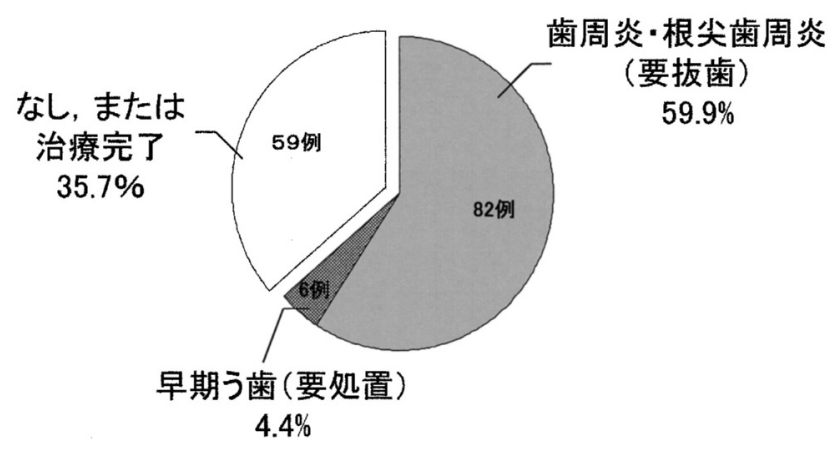

図 2 口腔内病変罹患率

表 2 手術

\begin{tabular}{cll}
\hline 弁置換術 113 例 & 大動脈弁置換 81 例 & $\begin{array}{l}\text { 機械弁 } 44 \text { 例 } \\
\text { 生体弁 } 37 \text { 例 }\end{array}$ \\
\cline { 2 - 3 } & 僧帽弁置換 22 例 & 機械弁 17 例 \\
& 生体弁 5 例 \\
\hline 三尖弁置換 1 例 & 生体弁 1 例 \\
\hline 二弁置換術 9 例 & 機械弁 7 例 \\
& 生体弁 2 例 \\
\hline
\end{tabular}

僧帽弁形成術 24 例 
表 3 菌血症となりうる口腔内病変を有する要抜歯患者群と有 しない抜歯不要患者群の比較

\begin{tabular}{|c|c|c|c|}
\hline & $\begin{array}{c}\text { 病変 }(+) \\
82 \text { 例 }\end{array}$ & $\begin{array}{c}\text { 病変 }(-) \\
55 \text { 例 }\end{array}$ & 有意差 \\
\hline 年齢（歳） & $65 \pm 11$ & $62 \pm 13$ & NS \\
\hline 男性 ～～～～～～～～～ & $49(60 \%)$ & $35(64 \%)$ & NS \\
\hline 大動脈弁疾患 & $47(57 \%)$ & $34(63 \%)$ & NS \\
\hline 僧帽弁疾患 & $28(34 \%)$ & $19(34 \%)$ & NS \\
\hline 連合弁膜症 & $7 \quad(9 \%)$ & $2 \quad(4 \%)$ & NS \\
\hline 感染性心内膜炎 & $10(12 \%)$ & $3 \quad(5 \%)$ & NS \\
\hline 心係数 & $2.3 \pm 0.5$ & $2.4 \pm 0.6$ & NS \\
\hline 抜歯のための入院 & $2 \quad(4 \%)$ & - & - \\
\hline 上顎洞根本手術 & $1 \quad(1 \%)$ & - & - \\
\hline 術後在院日数 & $16 \pm 12$ & $17 \pm 13$ & NS \\
\hline 術後在院日数 $(\mathrm{IE}$ 除く) & $15 \pm 11$ & $14 \pm 5$ & NS \\
\hline
\end{tabular}

IE : 感染性心内膜炎.
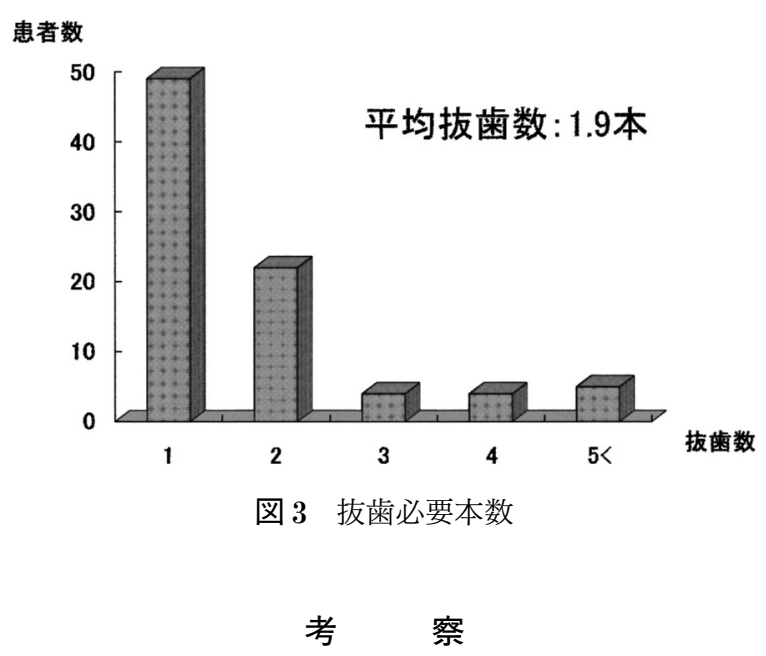

今回の 137 例の弁膜症手術対象患者（平均年齢 65 歳） に打ける, 菌血症となりうる口腔内病変の罹患率は $59.9 \%$ であり, 軽度の歯病変を合わせると口腔内病変罹患 率は $64.2 \%$ と高率であった。口腔内病変の一般的な罹患 率として, 60 歳から 64 歳までを対象とした厚生労働省の 平成 17 年歯科疾患実態調査によると, う歯の罹患率は 97\%と高率で，そのうち未処置のう歯罹患率は $38 \%$ で あったと報告されている4). 弁膜症手術症例における口腔 内病変の報告は少ないが，Terezhalmy らによると弁膜症 手術予定患者 156 人 (平均年齢 62.8 歳) のうち， $15.4 \%$ に歯根周囲の膿瘍を，43.6\%に歯周炎を認めたと報告され ている5)。また Krennmair らは 152 例の弁膜症手術患者 群の感染源となりうる口腔内病変の罹患率は $58 \%$ であり, 150 例の年齢, 性別, 居住地をマッチさせた非心臓疾患患 者群と比較し差はなかったと報告している ${ }^{6)}$. 以上より本 研究での結果と合わせても, 弁膜症手術予定患者が口腔内 病変を有している可能性は高いと思われる。

歯は顎骨の骨髄から直接，植立しているが，歯と歯肉が 硬い勒帯組織（防御機構）で結合しているために，口腔内
の膨大な数（10の 9 乗個以上）の常在菌からは防御され ている ${ }^{7,8)}$. しかし口腔内常在菌によって引き起こされた 歯周病や根尖性歯周炎が長期に存在, 炎症を繰り返すと, その防御機構が破綻し, 細菌が顎骨の骨髄に侵入して菌血 症を起こすと考えられている。

これらのリスクを回避するために, 術前に口腔内スク リーニング検查を行い，菌血症の予防策として抜歯を行う ことは重要と考えられる.

今回, 口腔内病変を有する患者の疫学的特徴があるかど うかを検討するために，口腔内病変を有する要抜歯患者群 （82 例）と有しない抜歯不要患者群（55 例）の術前状態の 比較を行ったが，年齢，疾患弁位，IE の有無，心拍出量 に有意差はなく疫学的な特徵は見出せなかった。また表 3 より疾患弁位別の口腔内病変罹患率を計算すると, 大動脈 弁疾患が $47 / 81$ 例 (58\%), 僧帽弁疾患が $28 / 47$ 例 $(60 \%)$ であり差はなかった。過去の報告では大動脈弁疾患患者の ほうが僧帽弁疾患患者よりその罹患率が高い $(70.4 \% \mathrm{vs.}$ 25.0\%）という報告もあったが6)，一方で歯周炎の他に顎 の囊胞や歯根を病変として含めると僧帽弁疾患患者のほう が大動脈弁疾患患者より罹患率が高い（61\% vs. 47\%）と いう報告も存在し ${ }^{9)}$ ，見解の一致はみていない。腔内病 変罹患率と心拍出量の関係に関しての報告はないが，一般 的に低心拍出で, 静脈圧が高くなれば感染のコントロール も不良となる。また口腔内病変と冠動脈疾患, 未梢血管病 変との関連性も多く論じられており．歯周病菌と動脈硬化 の関連性も報告されている ${ }^{10 \sim 12)}$ 。 心機能低下例や大動脈 弁狭窄症などの動脈硬化性弁膜症例での口腔内病変罹患率 が高い可能性が示唆される.

菌血症となりうる口腔内病変を有する患者は全例，術前 に抜歯を中心とした歯科治療を行い感染源となり得る部位 を除去した。抜歯に際しては感染症心内膜炎の予防と治療 に関するガイドラインにおける予防法に基づき，アモキシ シリン $2 \mathrm{~g}$ を抜歯の 1 時間前に服用し感染予防を行つ $た^{13)}$. 広範な口腔内病変を有した 3 例でその治療のため入 院が必要であったものの, その他に弁膜症手術前後を通し 歯科治療に伴う有害事象を認めなかった。また要抜歯患者 群でも抜歯不要患者群に比し術後在院日数の延長はなく, 術前後の経過に与える抜歯の影響は少ないと考えられた。 口腔内病変の治療を弁膜症手術前に行うか，術後に行うか に関しては, 弁膜症手術後患者はオッズ比 75 倍で IE を 発症するリスクが高いとされており ${ }^{3)}$ ，人工弁心内膜炎を 呈した際の重篤性，術後抗凝固療法の必要性を考慮する と，術前に歯科治療を行っておくことは適切であると考え られる。一般的に, 菌血症から IE の発症は 2 週間以内が 多いとされているため ${ }^{14)}$, 抜歯から手術までの期間をどの 程度あければよいかということに関しては今後の検討が必 
要である.

歯科治療後から術後平均観察期間 30 力月で IE の発症 はなく経過良好であった。しかしながら IE の罹患率自体 が低いこと, コントロール群がないことから, 術前の歯科 治療が術後のIE 予防にどれだけ寄与したかは言及でき ず，今後，更なる検討を要する。

\section{結語}

弁膜症手術症例の口腔内病変罹患率は高く, その多くは 菌血症の原因となりうる病態であった。それら口腔内病変 を有する患者に対し弁膜症手術前に安全に抜歯が可能であ

り，術後経過を遷延させることはなく良好な結果を得た。

\section{文献}

1) Donley, T. G. and Donley, K. B. : Systemic bacteremia following toothbrushing: A protocol for the management of patients susceptible to infective endocarditis. Gen. Dent. 36 : 482-484, 1988.

2) Nakatani, S., Mitsutake, K., Hozumi, T. et al.: Current characteristics of infective endocarditis in Japan-An analysis of 848 cases in 2000 and 2001. Circ. J. $67: 901-$ 905, 2003.

3) Strom, B. L., Abrutyn, E., Berlin, J. A. et al. : Dental and cardiac risk factors for infective endocarditis. A population-based, case-control study. Ann. Intern. Med. 129: 761-769, 1998.

4) 厚生労働省医政局歯科保健課. 平成 17 年歯科疾患実態調查
結果について. 2007 年 1 月 29 日掲載. http://www.mhlw. go.jp/topics/2007/01/tp0129-1.html.

5) Terezhalmy, G. T., Safadi, T. J., Longworth, D. L. et al. : Oral disease burden in patients undergoing prosthetic heart valve implantation. Ann. Thorac. Surg. 63: 402404, 1997.

6) Krennmair, G., Auer, J., Krainhöfner, M. et al. : Odontogenic infection sources in patients scheduled for cardiac valve replacement. Oral. Health Prev. Dent. 5 : 153-159, 2007.

7) Dubrul, E. I. ; 金澤英作訳 : 口腔内解剖学. 第 2 版, 医歯薬 出版, 東京, 1995, pp. 155-271.

8）藤田恒太郎：歯の解剖学. 第 22 版, 金原出版, 東京, 1995 , pp. 6-7.

9) Lassnig, E., Auer, J., Weber, T. et al. : Infection sources in HNO-and jawbone regions in patients before valve replacement surgery. Herz 29: 317-321, 2004.

10) Hung, H. C., Willett, W., Merchant, A. et al.: Oral health and peripheral arterial disease. Circulation 107 : 1152-1157, 2003.

11) Meurman, J. H., Sanz, M. and Janket, S. J. : Oral health, atherosclerosisk, and cardiovascular disease. Crit. Rev. Oral Biol. Med. 15 : 403-413, 2004.

12) Mendez, M. V., Scott, T., LaMorte, E. et al. : An association between periodontal disease and peripheral vascular disease. Am. J. Surg. 176 : 153-157, 1998.

13） 2001 2002 年度合同研究班: 感染症心内膜炎の予防と治 療に関するガイドライン. Circ. J. 67 Suppl. VI, 1039-1082, 2003.

14) Starkebaum, M., Durack, D. and Beeson, P.: The incubation period of subacute bacterial endocarditis. Yale J. Biol. Med. 50 : 49-58, 1997. 